\title{
Stomatal Density and Calcium Concentration of Six Snap Bean Cultivars
}

\author{
J.M. Quintana, ${ }^{1}$ H.C. Harrison, ${ }^{2}$ J.P. Palta, ${ }^{3}$ J. Nienhuis, ${ }^{4}$ and K. Kmiecik ${ }^{5}$ \\ Department of Horticulture, University of Wisconsin, Madison, WI 53706 \\ E. Miglioranza ${ }^{6}$ \\ Departamento de Agronomia, Universidade de Londrina, Londrina-PR, 86051,Brazil
}

AdDitional INDEX wORDs. pod growth, stomata, calcium uptake, environment, stem, and leaf

\begin{abstract}
Stomatal density of pods and leaves were determined for six commercial snap bean cultivars (Phaseolus vulgaris L. 'Evergreen', 'Hystyle', Labrador', 'Tenderlake', 'Top Crop', and 'Venture') grown at three planting dates, in an attempt to find morphological traits that could be related to cultivar differences in pod Ca concentration. Snap beans were planted three times at $\approx 1$-week intervals beginning 15 June 1995, and harvested 59 to 62 days after planting. Stomatal counts were performed using a microscope linked to a video camera, and Ca concentration determinations were made using atomic absorption spectrophotometry. Calcium concentration and stomatal density of leaf tissue was higher than that of pods. Cultivar differences for pod Ca concentration $(P=0.001)$ and stomatal density $(P=0.001)$ were observed although cultivars with higher pod stomatal density did not necessarily result in higher pod Ca concentration. Calcium concentration and stomatal density for leaves did not differ among cultivars. Stomatal density and Ca concentration of pods were positively correlated $\left(R^{2}=0.37\right)$, while pod maturity was negatively associated to both pod Ca concentration $\left(R^{2}=0.93\right)$, and pod stomatal density $\left(R^{2}=0.99\right)$. The effect of planting dates was absent in pod Ca concentration and significant in pod stomatal density.
\end{abstract}

Snap bean (Phaseolus vulgaris) is a vegetable with important economic value and rising popularity, with per capita consumption in the United States having increased $45 \%$ in the last 10 years (National Agricultural Statistical Service, 1997). Beans also have notable nutritional value, with high levels of protein, $\mathrm{Fe}, \mathrm{K}$, vitamin B (Ensminger et al., 1994), and Ca (USDA, 1984). Due to low levels of inhibitory compounds such as phytates and oxalates, snap beans posses relatively high $\mathrm{Ca}$ bioavailability levels (Vazquez Oderiz et al., 1994) and have been the focus of numerous studies investigating ways to augment pod $\mathrm{Ca}$ accumulation in pods. Initial screening experiments demonstrated genetic diversity for $\mathrm{Ca}$ concentration in snap bean pods and suggested that breeding might be considered the most attainable approach to pod $\mathrm{Ca}$ enhancement at the present time (Quintana et al., 1996). Several recent studies have explored whether Ca fertilizer applications might increase pod $\mathrm{Ca}$ levels and have consistently found this not to be the case (Miglioranza et al., 1997; Quintana et al., 1999).

Early research demonstrated that $\mathrm{Ca}$ moves into snap bean pods primarily by pod transpiration (Mix and Marschner, 1976a, 1976b). Recent work has indicated that differences between snap

Received for publication 12 July 1999. Accepted for publication 8 Sept. 2000. Research conducted at the University of Wisconsin, Madison WI. We appreciate the valuable aid of Erik V. Nordheim with statistical analyses, Michell E. Sass and Olufunmilayo Ewumi with technical assistance, and the constructive comments of Brent H. McCown and John C. Stier. From a PhD dissertation by J.M. Quintana. Research supported by the Graduate Research Committee at the Univ. of Wisconsin, Madison, the College of Agricultural and Life Sciences, and Hatch Act Funds. Use of trade names does not imply endorsement of the products named or criticism of similar ones not mentioned.

${ }^{1}$ Former graduate research assistant. The cost of publishing this paper was defrayed in part by the payment of page charges. Under postal regulations, this paper therefore must be hereby marked advertisement solely to indicate this fact. ${ }^{2}$ Professor and corresponding author: e-mail hcharris@ facstaff.wisc.edu.

${ }^{3}$ Campbell-Bascom professor.

${ }^{4}$ Associate professor.

${ }^{5}$ Research plant breeder.

${ }^{6}$ Professor. bean genotypes for pod $\mathrm{Ca}$ concentration may not be due to differences in net $\mathrm{Ca}$ influx at the whole plant level, but rather to Ca partitioning into fruits presumably resulting from pod transpiration (Grusak et al., 1996). Snap bean cultivars with higher pod $\mathrm{Ca}$ concentration levels may also have larger and/or more pod stomata which may lead to an increased rate in pod transpiration and correspondingly higher pod $\mathrm{Ca}$ accumulations. Soil $\mathrm{Ca}$ reaches the root surface mainly via mass flow (Barber, 1995). Translocation of absorbed $\mathrm{Ca}$ in the xylem occurs through mass flow of free $\mathrm{Ca}$ and some organically complexed $\mathrm{Ca}$, and by movement along $\mathrm{Ca}$ exchange sites in the xylem walls (Clarkson, 1984). Calcium appears immobile in the phloem (Peel, 1972) and is consequently not redistributed within the plant (Biddulph et al., 1959). Thus, the Ca needed during reproductive growth must be supplied directly by uptake (Barber, 1995).

Since $\mathrm{Ca}$ appears to enter snap bean pods as a result of pod transpiration rates, genotypes with high pod $\mathrm{Ca}$ concentration levels may have proportionally higher stomatal densities. The objectives of this investigation were to determine the 1) association between stomatal density and Ca concentration in snap bean pods and leaves, and 2) effects of planting date and pod maturity on the Ca concentration and stomatal density of snap bean pods.

\section{Materials and Methods}

EXPERIMENTAL DESIGN AND STATISTICAL ANALYSIS. This study was conducted at the University of Wisconsin, Agricultural Research Station, Hancock. Soil at the Hancock Station was classified as Plainfield loamy sand (sandy, mixed, mesic, Typic Udipsamment) with $1.2 \%$ organic matter. Soil analysis taken at preplant revealed a $\mathrm{pH}$ of $6.1,88 \mathrm{mg} \cdot \mathrm{L}^{-1} \mathrm{P}_{2} \mathrm{O}_{5}, 107 \mathrm{mg} \cdot \mathrm{L}^{-1} \mathrm{~K}_{2} \mathrm{O}$, and $580 \mathrm{mg} \cdot \mathrm{L}^{-1} \mathrm{Ca}$. The experiment was arranged as a randomized complete block repeated at each of the three planting dates. Each planting date consisted of two blocks with six snap bean cultivars each. Comparisons among cultivars were done using a LSD test (Snedecor and Cochran, 1991). Analyses of variance (ANOVA) for the data were performed using the GLM procedure 
of SAS (SAS Inst., Inc., Cary, N.C.) and regressions were done using Minitab software (Minitab, Inc., State College, Pa.).

Plant culture. Six commercially used snap bean cultivars differing in pod Ca concentration ('Evergreen', 'Hystyle', 'Labrador', 'Tenderlake', 'Top Crop', and 'Venture') were planted on 15, 22, and 28 June 1995. Plots consisted of one row $1.02 \mathrm{~m}$ long where 20 seeds were sown and thinned 20 to $30 \mathrm{~d}$ after planting to 10 seedlings per row. Rows were spaced $91 \mathrm{~cm}$ apart and blocks were spaced $60 \mathrm{~cm}$ apart. Standard cultural practices were followed (Binning et al., 1998). These practices included preplant incorporation of herbicide, trifluralin [2,6-dinitro-N,Ndipropyl-4-(trifloromethyl) benzenamine], cultivations and insecticide applications as needed, a single fertilizer application $(33 \mathrm{~N}-0 \mathrm{P}-0 \mathrm{~K})$ at a rate of $100 \mathrm{~kg} \cdot \mathrm{ha}^{-1}(\approx 2$ weeks after each planting), and an irrigation schedule of $12.5 \mathrm{~mm}^{3} \cdot \mathrm{week}^{-1}$. No Ca was added to the soil. Pods were commercially mature (Le Baron, 1974 ) and ready to harvest $\approx 59$ to $62 \mathrm{~d}$ after planting.

SAMPLING AND POSTHARVEST PROCEDURE. Two plants were randomly selected from each plot at harvest date. Foliage area and yield were recorded for each plant. Foliage area was estimated by stripping off the leaves of each plant and measuring the area of each individual leaf with a leaf area meter (LI-3100; LI-COR, Lincoln, Neb.). Thus, foliage area per plant was defined as the total leaf area $\left(\mathrm{cm}^{2}\right)$ recorded for each plant. Yield was defined as the total fresh weight (FW) of all pods collected per each plant and expressed as $\mathrm{g} \cdot \mathrm{m}^{-2}$. Pods were separated according to commercial standard sizes that correspond to the following diameters: size 1 $=\leq 5.8 \mathrm{~mm}, 2=>5.8$ to $7.2 \mathrm{~mm}, 3=>7.2$ to $8.2 \mathrm{~mm}, 4=>8.2$ to $9.4 \mathrm{~mm}$ and $5=>9.4$ to $10.7 \mathrm{~mm}$ (Mayland and Dean, 1971). Samples collected from each plant included the terminal leaflet of the first compound leaf counting basipetally and one fruit of each size. Stomatal density and $\mathrm{Ca}$ concentration of pods and leaves were determined. For analytical purposes, data from the two sampled plants in each plot were pooled.

Stomatal DENSITY DETERMinations. The procedure used for stomatal impressions of leaves and pods was an adaptation of that used to screen potato (Solanum L. sp.) populations for freezing tolerance (Kleinhenz et al., 1995). It consisted of: 1) taking a piece of cellophane tape, 2) affixing it to a glass slide, 3) partially dissolving the tape by allowing five drops of acetone to stand on it for 3 to $5 \mathrm{~s}, 4$ ) removing the excess acetone by shaking the slide, and 5) pressing the leaf or pod gently into the dissolved tape for $3 \mathrm{~s}$. Stomatal readings were performed using a microscope linked to a videocamera. Pod and leaf stomata were hand marked on transparent sheets of polyethylene held by static electricity to the television screen and all stomata counting was done in a $0.3-\mathrm{mm}^{2}$ area. Each stoma was defined as the guard cells-stomatal pore complex. For each slide two countings were performed at random, and the pooled number recorded (stomata/ $/ 0.3 \mathrm{~mm}^{2}$ ). Stomatal impressions were obtained the day of harvest under laboratory conditions. On leaves, stomatal impressions were performed on the adaxial leaf surface from the area between the midvein and margins. For pods, stomatal impressions were performed on both sides of the mid section of the pod.

Calcium concentration determinations. Leaf and pod samples were oven-dried at 60 to $65^{\circ} \mathrm{C}$ for $24 \mathrm{~h}$. Dried samples were ground in a Wiley mill to pass a $10-\mathrm{mesh}(2.5-\mathrm{mm})$ screen. Aliquots of $0.05 \mathrm{~g}$ for pods and $0.03 \mathrm{~g}$ for leaves were weighed and placed into $10-\mathrm{mL}$ glass beakers. Samples were dry-ashed in a muffle furnace at $450^{\circ} \mathrm{C}$ for $5 \mathrm{~h}$. When the samples were cool, $\mathrm{Ca}$ was extracted by adding $5 \mathrm{~mL}$ of $2 \mathrm{~mol} \cdot \mathrm{L}^{-1} \mathrm{HCl}$ to dissolve the ash. This solution was poured through Whatman no. 540 filter paper and collected into a 50-mL volumetric flask. Filter paper was rinsed with two to three volumes of distilled-deionized water to ensure that all Ca was extracted from the ash. Finally, $10 \mathrm{~mL}$ of $0.2 \mathrm{~mol} \cdot \mathrm{L}^{-1} \mathrm{HCl}$ containing $10,000 \mathrm{mg} \cdot \mathrm{L}^{-1}$ lanthanum $\left(\right.$ as $\left.\mathrm{LaCl}_{3}\right)$ was added and the total volume was adjusted to $50 \mathrm{~mL}$ with distilled-deionized water. Calcium analyses were conducted using atomic absorption spectrophotometry (model Spectra AA20; Varian Techtron Pty. Limited, Mulgrave Victoria, Australia).

Table 1. ANOVA for calcium concentration and stomatal density of six commercial cultivars of snap beans across planting dates. ${ }^{\mathrm{Z}}$

\begin{tabular}{|c|c|c|c|c|}
\hline Source & df & Mean square & F value & $P>\mathrm{F}$ \\
\hline & \multicolumn{4}{|c|}{ Pod stomatal density (stomata/0.3 mm²) } \\
\hline Planting date (PD) & 2 & 288.52 & 7.14 & $0.001^{* * * *}$ \\
\hline Block nested in PD & 3 & 37.65 & 0.62 & 0.603 \\
\hline Cultivar (C) & 5 & 1961.30 & 19.40 & $0.001^{* * * *}$ \\
\hline $\mathrm{C} \times \mathrm{PD}$ & 10 & 311.17 & 1.54 & 0.135 \\
\hline $\mathrm{C} \times$ block nested in $\mathrm{PD}$ & 15 & 464.32 & 1.53 & 0.106 \\
\hline Pod size ( PS ) & 4 & 190.70 & 2.36 & 0.058 \\
\hline $\mathrm{PS} \times \mathrm{PD}$ & 8 & 1020.24 & 6.31 & $0.001^{* * * *}$ \\
\hline $\mathrm{PS} \times \mathrm{C}$ & 20 & 934.99 & 2.31 & $0.003^{* *}$ \\
\hline \multirow[t]{2}{*}{ Pooled error } & 110 & 2223.78 & & \\
\hline & \multicolumn{4}{|c|}{ Pod Ca concn $\left(\mathrm{mg} \cdot \mathrm{g}^{-} 1 \mathrm{DW}\right)$} \\
\hline PD & 2 & 1.23 & 0.33 & 0.803 \\
\hline Block nested in PD & 3 & 5.91 & 1.19 & 0.317 \\
\hline $\mathrm{C}$ & 5 & 22.64 & 3.65 & $0.004^{* *}$ \\
\hline $\mathrm{C} \times \mathrm{PD}$ & 10 & 30.49 & 1.64 & 0.071 \\
\hline $\mathrm{C} \times$ block nested in PD & 15 & 49.91 & 2.01 & $0.010^{* *}$ \\
\hline PS & 4 & 26.36 & 5.31 & $0.001^{* * * *}$ \\
\hline $\mathrm{PS} \times \mathrm{PD}$ & 8 & 18.07 & 1.21 & 0.279 \\
\hline $\mathrm{PS} \times \mathrm{C}$ & 20 & 46.87 & 1.89 & 0.017 \\
\hline Pooled error & 110 & 173.57 & & \\
\hline
\end{tabular}

${ }^{\mathrm{z}}$ Analyses performed across pod sizes.

$* * * * *$ Significant at $P=0.01$ or 0.001 , respectively. 


\section{Results and Discussion}

Pod Ca Concentration and stomatal Density. ANOVA showed significant differences among cultivars for Ca concentration and stomatal density on snap bean pods (Table 1). However, the correlation of pod concentration of $\mathrm{Ca}$ with stomatal density was weak $\left(R^{2}=0.37\right)$. Cultivars with highest pod stomatal density did not reflect the highest values for pod Ca concentration. For example, 'Evergreen' showed the highest stomatal density (37 stomata/ $/ 0.3 \mathrm{~mm}^{2}$ ) but only the fourth highest pod Ca concentration $\left[4.7 \mathrm{mg} \cdot \mathrm{g}^{-1}\right.$ dry weight (DW)] (Fig. 1). Comparisons of actual mean values for each cultivar for pod stomatal density and pod $\mathrm{Ca}$ concentration across pod sizes showed that cultivar rankings differed for the variables evaluated (Fig.1). 'Tenderlake', 'Hystyle' and 'Top Crop' had the highest pod Ca concentration levels (averaged over all pod sizes) followed by 'Evergreen' and 'Venture' with 'Labrador' exhibiting the lowest values. The groupings changed somewhat when pod stomatal density was measured with 'Evergreen', 'Hystyle' and 'Tenderlake' having the highest densities followed by 'Venture' and 'Top Crop'. 'Labrador' again had the lowest values. There was a decrease of pod $\mathrm{Ca}$ concentration and pod stomatal density as pods grew for all snap

Fig. 1. Mean pod Ca concentration (.) and stomatal density (o) for each pod size and across pod sizes on six commercial cultivars of snap bean. Pod $\mathrm{Ca}$ concentration and stomatal density values denote means calculated across three planting dates. Pod Ca concentration means across pod sizes are separated by $\operatorname{LSD}_{0.01}=0.79$, and stomatal density means by $\operatorname{LSD}_{0.01}=3.59$. Means across pod sizes were calculated from averaging the mean values for each grade size.

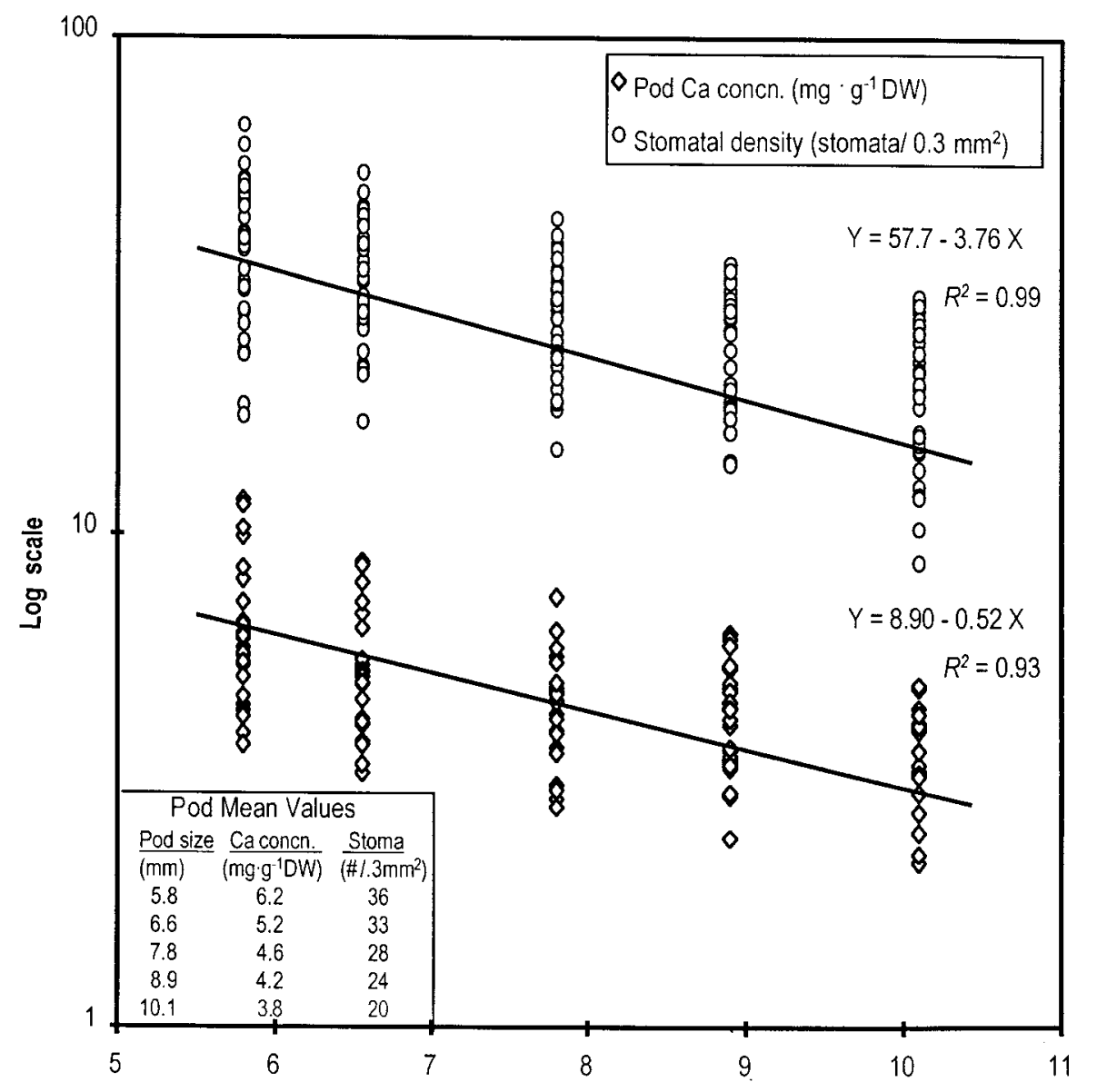

Pod size (diameter in $\mathrm{mm}$ ) bean cultivars evaluated. Nevertheless, a significant positive correlation coefficient of $R^{2}=0.37$ was found in the regression analysis using pod $\mathrm{Ca}$ concentration as a dependent variable and pod stomatal density as the independent variable. This implies that although pod stomatal density appears to have some effect on pod $\mathrm{Ca}$ concentration, its role does not adequately explain the observed variability for pod $\mathrm{Ca}$ concentration in snap beans.

Results herein suggest that perhaps mechanisms other than stomata density play an influential role in causing differences for pod Ca concentration among cultivars in snap beans. Factors could include 1) transpiration itself, 2) stomata size because proportional relationships exist between water loss through transpiration and pore diameter (Brown and Escombe, 1900; Ting and Loomis, 1963), and water loss and pore area (Lee, 1967), or 3) root pressure which results in night delivery of $\mathrm{Ca}$ to low or nontranspiring organs within the plant (Palzkill and Tibbitts, 1977).

CalCiUM CONCENTRATION AND STOMATAL DENSITY ON LEAVES. No differences among cultivars were detected for Ca concentration or stomatal density of leaves. These results seem logical because Ca moves into the leaves mainly via transpiration during $\mathrm{CO}_{2}$ uptake (Willmer and Fricker, 1996) and since $\mathrm{Ca}$ is not redistributed (Palta, 1996), it tends to accumulate there. Therefore, meaningful differences for Ca concentration in leaves may not be expected among cultivars (assuming that leaf sampling is done from the same plant part for all cultivars) when one considers that $\mathrm{CO}_{2}$ uptake (in the day light) is a continuous process during the life cycle of the bean plant. Calcium concentration in leaves (overall mean of $27.8 \mathrm{mg} \cdot \mathrm{g}^{-1} \mathrm{DW}$ ) was higher than pod $\mathrm{Ca}$ concentration (3.5 to $\left.6.0 \mathrm{mg} \cdot \mathrm{g}^{-1} \mathrm{DW}\right)$. Similarly, stomatal density in leaves $\left(56\right.$ stomata $\left./ 0.3 \mathrm{~mm}^{2}\right)$ was higher than pods ( 21 to 37 stomata/ $0.3 \mathrm{~mm}^{2}$ ).

Although significant, a relatively low association between $\mathrm{Ca}$ concentration and stomatal density in pods was detected, indicating that cultivar differences for pod $\mathrm{Ca}$ concentration might not be caused solely by differences in stomatal density. Possibly, mechanisms such as root pressure and transpiration or morphological attributes such as stoma size might influence accumulation of $\mathrm{Ca}$ in bean pods.

LEAF AREA AND YIELD. No correlation was detected among leaf area and yield and pod Ca concentration or stomatal density. Overall means for yield and leaf area were 1913 $\mathrm{g} \cdot \mathrm{m}^{-2}$ and $3809 \mathrm{~cm}^{2}$, respectively. Yield differences were highly significant among cultivars $(P=0.001)$. 'Tenderlake' (2310 $\left.\mathrm{g} \cdot \mathrm{m}^{-2}\right)$ and 'Hystyle' $\left(2266 \mathrm{~g} \cdot \mathrm{m}^{-2}\right)$ were the highest yielders and 'Labrador' (1403 g.m$\left.{ }^{2}\right)$ the lowest. Cultivar mean comparisons resulted in 'Top Crop' $\left(4346 \mathrm{~cm}^{2}\right)$ having the highest leaf area which differed significantly from 'Venture' $\left(2709 \mathrm{~cm}^{2}\right)$ which had the lowest. Cultivars with higher pod $\mathrm{Ca}$ concentration ('Tenderlake') did not reflect higher leaf areas. A recent study suggested that differences for pod $\mathrm{Ca}$ concentration among snap bean cultivars were not caused by differences in the total plant $\mathrm{Ca}$ influx 


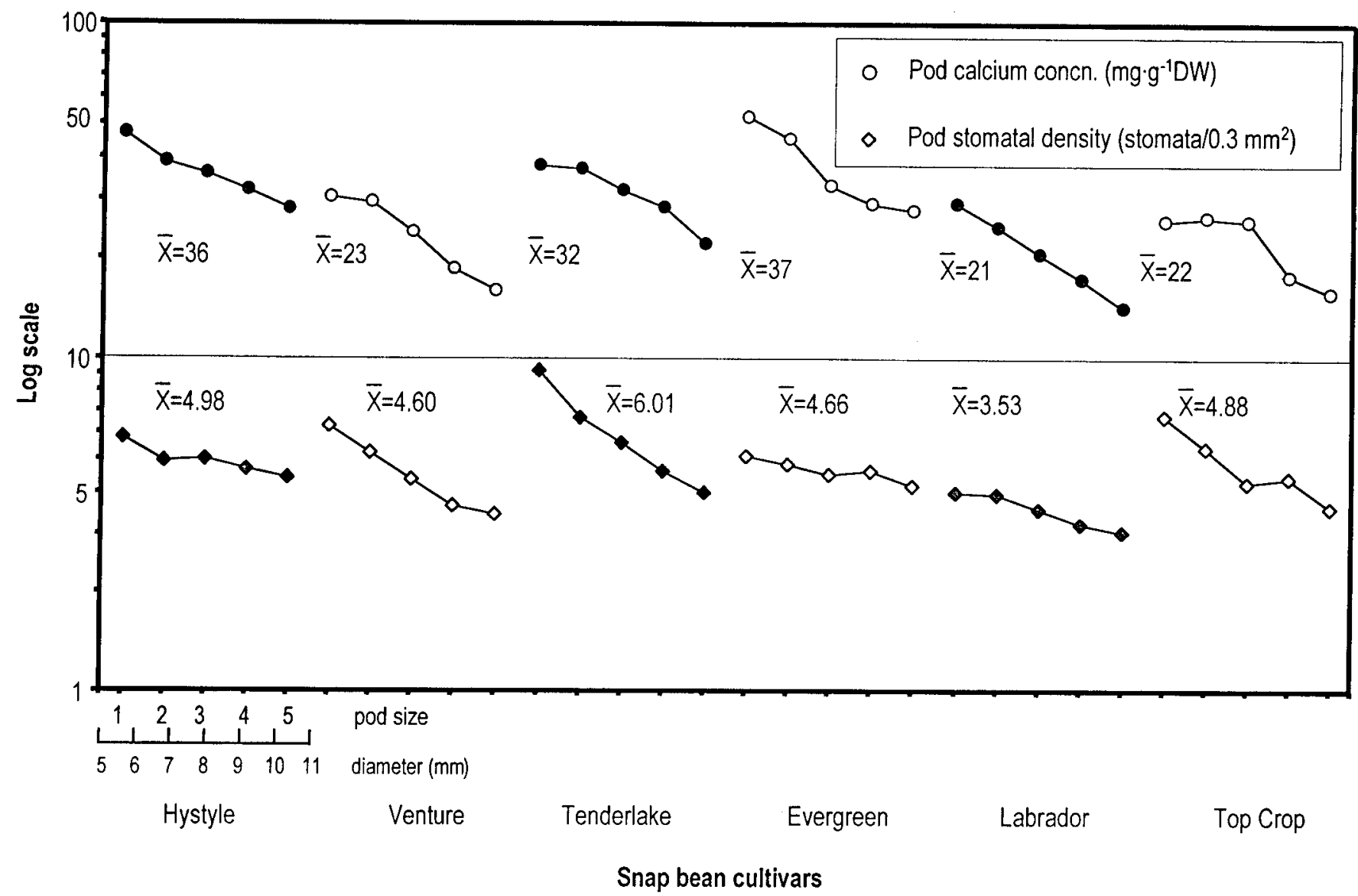

Fig. 2. Effect of pod maturity on pod Ca concentration and stomatal density for six snap bean cultivars harvested at Hancock, Wis.

(Grusak et al., 1996). Results from our study seem to support this theory because a higher leaf area could be interpreted as a large total $\mathrm{Ca}$ influx since leaves accumulate most of the $\mathrm{Ca}$ in the bean plant and cultivars with larger leaf area did not result in higher pod Ca concentration.

Planting Date. Planting date had no significant impact on $\mathrm{Ca}$ concentration of leaves and pods even though temperature and rainfall varied considerably over the three plantings. Accumulated precipitation in addition to the scheduled irrigation (12.5 $\mathrm{mm} \cdot \mathrm{week}^{-1}$ ) ranged from a low of $134 \mathrm{~mm}$ for the first planting (seeded 9 June 1995), to a high of $246 \mathrm{~mm}$ for the third planting (seeded 22 June 1995). Accumulated heat units (base $10{ }^{\circ} \mathrm{C}$ ) ranged from a low of 1317 units for the first planting to a high of 1535 units for the second planting (seeded 15 June 1995). Despite these environmental variations, planting date differences were absent for $\mathrm{Ca}$ concentration of pods (Table 1), and leaves. Planting date $\mathrm{x}$ cultivar interactions were not detected for $\mathrm{Ca}$ concentration of leaves and hardly significant for pod Ca concentration (Table 1), suggesting that environmental variation had little effect on Ca concentration in the snap bean treatment plants. This agrees with our previous studies (Quintana et al., 1996). Statistical significance was present for pod stomatal density among planting dates $(P=0.001)$ but not for planting date $\times$ cultivar interaction (Table 1); likewise, significant differences $(P$ $=0.02$ ) were detected for leaf stomatal density among planting dates.

As expected, yield was significantly affected by environment $(P=0.001)$, but leaf area was not (data not presented). Although higher heat unit accumulations (e.g., second planting) were not reflected in increased yields, elevated precipitation levels (e.g., third planting) provided higher yields.

POD MATURITY AND ITS EFFECT ON STOMATAL DENSITY AND CA CONCENTRATION. The effect of pod size on pod Ca concentration and stomatal density was evident in this study. As pods mature their Ca concentration and stomatal density decrease (Fig. 2). These results are in agreement with previous studies reporting the effect of pod maturity (Mills and Jones, 1979; Quintana et al., 1996) and pod growth rate (Mix and Marschner, 1976c) on Ca concentration in snap beans.

Apparently, as a pod matures, its total Ca content increases but not at the same rate as the pod grows (increases in size), thus, its $\mathrm{Ca}$ concentration decreases. Even though this conclusion is somewhat beyond the scope of this study, it can be made based on results of previous investigations (Grusak et al., 1996; Mix and Marschner, 1976c). The relationship between pod size and stomatal density might be interpreted as follows: as a pod grows, the total number of stomata remains constant or increases at a very slow rate; thus the stomata number in relation to area drops dramatically as the pod ages.

\section{Literature Cited}

Barber, S.A. 1995. Soil nutrient bioavailability: A mechanistic approach. $2^{\text {nd }}$ ed. Wiley, New York.

Biddulph, O., R. Cory, and S. Biddulph. 1959. Translocation of calcium in the bean plant. Plant Physiol. 34:512-519.

Binning, L.K., C.M. Boerboom, L.G. Bundy, T.R. Connell, E.T. Gritton, H.C. Harrison, H.J. Hopen, K.A. Kelling, S.E.R. Mahr, B.A. Michaelis, L.A. Peterson, P.J. Schmidt, W.R. Stevenson, W.F. Tracy, J.L. 
Wedberg, and J.A. Wyman. 1998. Commercial vegetable production in Wisconsin. Univ. Wis. (Madison) Ext. Serv. Bul. A3422.

Brown, H. and F. Escombe. 1900. Static diffusion of gases and liquids in relation to the assimilation of carbon and translocation in plants. Phil. Trans. Roy. Soc. Lond. Ser. B. 193:233-291.

Clarkson, D.T. 1984. Calcium transport between tissues and its distribution in the plant. Plant Cell Environ. 7:449-456.

Ensminger, E., M.E. Ensminger, J.E. Konlande, and J.R.K. Robson. 1994. Foods and nutrition encyclopedia. $2^{\text {nd }}$ ed. vol. 1. CRC Press, Boca Raton, Fla.

Grusak, M.A., B.W. Stephens, and D.J. Merhaut. 1996. Influence of whole-plant net calcium influx and partitioning on calcium concentration in snap bean pods. J. Amer. Soc. Hort. Sci. 121:656-659.

Kleinhenz, M.D., J.B. Bamberg, and J.P. Palta. 1995. Use of stomatal index as a marker to screen backcross populations of two wild potato species segregating for freezing tolerance. Amer. Potato J. 72:243250.

Le Baron, M.J. 1974. Developmental stages of the common bean plant. Univ. of Idaho, Moscow. Current Info. Ser. 228.

Lee, R. 1967. The hydrologic importance of transpiration control by stomata. Water Res. 3:737-752.

Mayland, H.F. and L.L. Dean. 1971. Chlorophyll content of persistentgreen and normal snap bean pods (Phaseolus vulgaris L.). J. Amer. Soc. Hort. Sci. 96:362-365.

Miglioranza, E., P. Barak, K. Kmiecik, and J. Nienhuis. 1997. Comparison of soil and genotypic effects on calcium concentration of snap bean pods. HortScience 33:68-70.

Mills, H.A. and J.B. Jones, Jr. 1979. Elemental content of frozen snap bean fruit. HortScience 14:268-269.

Mix, G.P. and H. Marschner. 1976a. Calciumgehalte in Früchten von Paprika, Bohne, Quitte und Hagebutte im Verlauf des Fruchtwachstums (Calcium content in fruits of paprika, bean, quince and hip during fruit growth). Z. Pflanzenernaehr. 5:537-549.

Mix, G.P. and H. Marschner. 1976b. Einflub exogener und endogener Faktoren auf den Calciumgehalt von Paprika und Bohnenfrüchten [Effect of external and internal factors on the calcium content of paprika (pepper) and bean fruits]. Z. Pflanzenernaehr. 5:551-563.
Mix, G.P. and H. Marschner. 1976c. Calcium-Umlagerung in Bohnenfrüchten während des Samenwachstums (Redistribution of calcium in bean fruits during seed development). Z. Pflanzenphysiol. 80:354-366.

National Agricultural Statistics Service. 1997. Agricultural statistics 1997. U.S. Govt. Printing Office, Washington, D.C.

Palta, J.P. 1996. Role of calcium in plant responses to stresses: Linking basic research to the solution of practical problems. In: M. Wisniewski (eds.). Recent advances in plant responses to stress: Bridging the gap between science and technology. HortScience 31:51-57.

Palzkill, D.A. and T.W. Tibbitts. 1977. Evidence that root pressure flow is required for calcium transport to head leaves of cabbage. Plant Physiol. 60:854-856.

Peel, A.J. 1972. The control of solute movement into sieve elements. Pesticide Sci. 3:631-641.

Quintana, J.M., H.C. Harrison, J. Nienhuis, J.P. Palta, and M.A. Grusak. 1996. Variation in calcium concentration among sixty $S_{1}$ families and four cultivars of snap bean (Phaseolus vulgaris L.). J. Amer. Soc. Hort. Sci. 121:789-793.

Quintana, J.M., H.C. Harrison, J.P. Palta, J. Nienhuis, and K. Kmiecik. 1999. Calcium fertilizers fail to affect pod calcium concentration and yield of four snap bean cultivars. HortScience 34:646-647.

Snedecor, G.W. and W.G. Cochran. 1991. Statistical methods. $8^{\text {th }}$ ed. Iowa State Univ. Press, Ames.

Ting, I.P. and W.E. Loomis. 1963. Diffusion through stomates. Amer. J. Bot. 50:866-872.

U.S. Department of Agriculture. 1984. USDA agricultural handbook series 8. Composition of foods: Vegetables and vegetable productsraw, processed, prepared. Nutrition Monitoring Div., Human Nutrition Info. Serv., USDA, Hyattsville, Md.

Vazquez Oderiz, M.L., M.E. Vazquez Blanco, J. Lopez Hernandez, J. Simal Lozano, and M.A. Romero Rodriguez. 1994. Simultaneous determination of organic acids and vitamin $\mathrm{C}$ in green beans by liquid chromatography. J. AOAC Intl. 77:1056-1059.

Willmer, C. and M. Fricker. 1996. Stomata. $2^{\text {nd }}$ ed. Chapman and Hall, New York. 